\title{
Aspectos da decisão saneadora sob \\ a perspectiva do novo Código de Processo Civil
}

\section{ASPECTS OF SANITIZING DECISION UNDER THE prospect of the new Civil Procedure Code}

\author{
Leonardo Greco *
}

Resumo: Na esteira das modificações implementadas pela sistemática proposta pelo Projeto do Novo Código de Processo Civil, a posição do juiz na condução do procedimento coloca-se cada vez mais relevante. Na pretensão de eficácia e efetividade ao processo, o saneamento é instrumento capaz de corrigir vícios e irregularidades, promovendo a escolha e produção das provas que propiciem o provimento jurisdicional final sobre o direito material das partes. Para tanto, realiza-se uma análise da importância da função saneadora, descrevendo-se a origem e a finalidade do despacho saneador. A seguir, são analisadas as características do despacho saneador, sua relação com o princípio da oralidade e seu conteúdo. Ao final, verifica-se a questão da preclusão no despacho saneador, concluindo-se por uma análise crítica das modificações sugeridas no Projeto de Novo Código de Processo Civil.

Palavras-chave: Saneamento. Projeto. Novo Código de Processo Civil.

Abstract: In the systematic of the changes implemented by the proposal of the new Civil Procedure Code project, the position of judge in the conduction of the process is increasingly relevant. On the pretense of efficiency and effectiveness to the process, sanitation is an instrument able to correct defects and irregularities, promoting the choice and production of evidence that alow the court to provide the substantive right of the parties. The present study analysis the importance of sanitizing function, describing the origin and purpose of the curative act. Next, it is analyzed the characteristics of the judicial act, its relationship with the principle of orality and its contents. At the end, there is the issue of stoppel in the curative act, concluding with a critical analysis of the changes suggested in the New Civil Procedure Code project.

Keywords: Sanitation. Project. New Civil Procedure Code. 


\section{INTRODUÇÃO}

Grande parte da atividade do juiz, dos seus auxiliares e das partes no processo civil se destina a prover à regularidade formal do processo, ao preenchimento dos pressupostos processuais e condições da ação, à correção de vícios e irregularidades e à escolha e produção das provas que propiciem o provimento jurisdicional final sobre o direito material das partes. Numerosos atos são praticados, incontáveis exigências são cumpridas, provocando sucessivos movimentos que conduzem a relação processual em direção ao seu fim último, que é o exercício da jurisdição sobre a pretensão de direito material.

Nesse percurso, que pode ser mais ou menos longo e mais ou menos complexo, todos os sujeitos do processo têm a sua parcela de responsabilidade, para que o resultado almejado seja alcançado, embora a medida em que cada sujeito deva atuar na sua composição possa variar de um país para o outro. Quero dizer com essa afirmação que há países em que o impulso processual é predominantemente do juiz, como o nosso, mas existem outros em que esse impulso compete acentuadamente às partes; que há países em que serventuários exercem muitas atividades que em outros são exercidas pelo juiz, como a prática dos atos executórios; assim como existem aqueles em que atos de comunicação são praticados pelos advogados, enquanto em outros o são por serventuários. Esses são apenas alguns exemplos de algumas escolhas que cada ordenamento processual faz, influenciadas por inúmeros fatores extrajurídicos, como a tradição, a capacidade técnica de certos sujeitos, a sua credibilidade na sociedade, o desenho ideal dos papéis que os juízes, os serventuários e os advogados devem desempenhar e o que a sociedade deles espera.

O padrão de qualidade da justiça brasileira pode ser definido a partir da realidade operacional da Justiça Federal, a única efetivamente nacional, dotada de satisfatórios meios materiais e humanos, de planejamento, de organização, de níveis de remuneração e de programas de capacitação profissional de serventuários, distribuída homogeneamente em todo o País, inclusive no interior. Mas a Justiça Federal não retrata a Justiça brasileira como um todo e um Código de Processo Civil, que acredite contar com uma organização judiciária ágil, rápida e econômica, capaz de tirar o máximo proveito dos modernos meios de comunicação e de gestão, estará longe da realidade brasileira e fadado ao insucesso.

Se essas condições existissem, eu não teria dúvidas em sugerir a adoção do modelo inglês da condução do processo pelo master, um serventuário 
qualificado, que impulsiona e saneia o processo e adota todas as decisões preparatórias do julgamento, como o deferimento das provas, reservando para o juiz a supervisão da sua atuação, a presidência das audiências e a prolação das decisões mais importantes, como as liminares e as sentenças (VARANO, 1973, passim). Na Alemanha, perante um serventuário qualificado, o Rechtspfleger, tramitam certos procedimentos de cobrança de dívidas, sem qualquer participação do juiz (MURRAY; STÜRNER, 2004, p.74-76). Na França, na Alemanha, na Itália, hoje em Portugal, quem determina os atos executórios é um oficial de justiça ou outro agente específico, sobre o qual o juiz exerce uma distante supervisão. Sugeriria também, e isso não me parece tão difícil de realizar, a autorização aos advogados de promoverem a maior parte dos atos de comunicação processual, especialmente os que se cumprem por simples publicações no Diário da Justiça ou pelos Correios, pois, desde que documentados no processo, para a segurança do seu conteúdo, não há diferença entre a sua realização por eles ou pelo serventuário da Justiça.

Enquanto não alcançamos esse nível de desenvolvimento humano, em caráter homogêneo nas diversas organizações judiciárias - se é que algum dia alcançaremos -, grande avanço poderíamos ter em muitas justiças estaduais se abandonássemos a regra constitucional oriunda da Constituição de 1934, que conferiu à União a competência privativa para legislar sobre direito processual, passando a atribuir essa competência concorrentemente aos Estados.

Poder-se-ia alegar que a Constituição de 1988 já permitiu essa legislação complementar dos Estados ao instituir no art. 24 a competência concorrente da União e dos Estados para legislar sobre "procedimentos em matéria processual". Essa disposição caiu no vazio, a meu ver por duas razões: em primeiro lugar, porque a legislação processual federal é exaustiva em matéria de procedimentos, não abrindo espaço para qualquer legislação complementar dos Estados; e, em segundo lugar, porque o que exige flexibilidade e adequação às diversas realidades judiciárias não são precipuamente os diversos procedimentos judiciais, mas as funções atribuídas aos diversos sujeitos processuais e a operacionalização da sua redistribuição.

À falta dessa flexibilidade, deparando-se com os contrastes existentes na justiça do País, o legislador processual, que precisa avançar na adoção das novas tecnologias, tem optado pela solução nada democrática de atribuir a complementação das suas regras, para adequação às peculiaridades locais, a resoluções dos tribunais. Sacrifica-se o princípio da legalidade, enfraquece-se a autoridade da lei, pois aos juízes e aos tribunais muitas vezes preocupa mais a 
observância desses regulamentos do que da própria lei, sem falar que muitos desses atos, que tratam de matérias tipicamente processuais, são editados por órgãos não jurisdicionais, como o Conselho Nacional de Justiça e o Conselho Nacional do Ministério Público, sem autorização legal, dispondo com frequência em sentido oposto ao da própria lei.

Uma outra constatação precisa ser feita para auxiliar na análise e avaliação da disciplina do saneamento do processo no projeto de novo Código de Processo Civil. É a de que um processo ágil, célere e, ao mesmo tempo, justo sob a perspectiva do contraditório irrestrito e da amplitude da defesa, há de ser um processo bifásico (TARUFFO, 2009, p.120), ou seja, um processo concentrado, estruturado em duas fases que culminem nas duas decisões mais importantes do processo, o julgamento conforme o estado do processo e a sentença final; em síntese, um processo que não seja truncado a todo momento por novos incidentes que exijam do juiz a prolação de uma série infindável de decisões sobre questiúnculas que vão surgindo no seu curso.

Cappelletti, em uma das suas famosas pesquisas de direito comparado (1971, passim), dedicada ao procedimento oral e ao procedimento escrito, criticou os sistemas processuais ibero-americanos, que identificou como os mais fragmentados do mundo. Esse é um fenômeno cultural, é o modo de ser da nossa Justiça, que o próprio legislador tem dificuldade de modificar. Há uma tendência atávica, de origem lusitana, que já tentei explicar em outros estudos, a compartimentar o processo numa série de decisões de pouca relevância, que o vão impulsionando aos solavancos pela estrada do procedimento, muitas vezes dando marcha a ré para reconsiderar ou modificar o que já fora decidido. Como bem aponta Cappelletti, é um modelo burocrático de exercício da jurisdição, muito cômodo para o juiz, porque a cada momento ele se debruça apenas sobre uma particularidade do processo, em geral fechando os olhos para o que já foi decidido, que é fato consumado, e para o que ainda terá de decidir, em que ele não tem de pensar agora. E, assim, as centenas de processos que ele tem diariamente de despachar saem rapidamente da sua mesa e ao final de cada dia ele tem a agradável sensação do dever cumprido. E se ele tem poucos processos para despachar, mais rapidamente a sua mesa se esvazia e ele pode dedicar o seu tempo a ocupações mais desfrutáveis.

Conforme observação pertinente de Heitor Sica, a partir das Ordenações Afonsinas o juiz foi autorizado a revogar de ofício quaisquer decisões interlocutórias até a sentença, sistema que vigorou entre nós por séculos, passando incólume pela legislação do Império (SICCA, 2006, p.42-44). 
Faça-se justiça aos países de que herdamos essa tradição, Espanha e Portugal. Seus ordenamentos atuais reagiram vigorosamente contra essa fragmentação. Assim, na primeira, a Ley de Enjuiciamiento Civil de 2000, no art. 207.2, assim como a sua anterior de 1881 (art. 363.1), filiou-se a um sistema preclusivo bastante rígido, que reveste de coisa julgada formal todas as decisões interlocutórias irrecorríveis, irrecorridas ou que, impugnadas por recurso, tenham sido confirmadas pelo tribunal; e, no segundo, o atual art. $580^{\circ}$, n. 3, do Código de Processo Civil preceitua que a decisão no saneador que houver apreciado concretamente as exceções dilatórias e as nulidades processuais que hajam sido suscitadas pelas partes, bem como as matérias apreciáveis de ofício, assim que se torne irrecorrível, constituirá coisa julgada formal.

Também no Brasil a instituição do despacho saneador teve essa inspiração: racionalizar a atividade instrumental do juiz pra conduzi-la com mais eficiência a um resultado útil. Examinemos em que medida o saneamento do processo cumpre esses objetivos e pretende cumpri-los na disciplina prevista no Projeto de Lei no 8.046 de 2010, ora em tramitação na Câmara dos Deputados e que se destina à adoção de um novo Código de Processo Civil.

\section{IMPORTÂNCIA DA FUNÇÃO SANEADORA}

O saneamento do processo é uma função instrumental do juiz, que abrange todas as atividades que ele exerce e todos os provimentos que adota, com a finalidade de assegurar a sua válida formação e o seu desenvolvimento regular e para definir os atos que deverão ser praticados para conduzi-lo à realização do seu fim, que é o justo e adequado exercício da jurisdição sobre a pretensão de direito material que lhe foi submetida. É, portanto, natural que qualquer ordenamento processual procure disciplinar essa função que, como já dissemos, é tradicionalmente atribuída no Brasil ao próprio magistrado, conforme estabelece o artigo 118 do Projeto de novo Código de Processo Civil (Projeto de Lei 8.046 de 2010, da Câmara dos Deputados), que, nesse aspecto não difere do Código em vigor (art. 125), estabelecendo que "o juiz dirigirá o processo conforme as disposições deste Código, incumbindo-lhe: I - promover o andamento célere da causa; [...] IX - determinar o suprimento de pressupostos processuais e o saneamento de outras nulidades processuais".

A função saneadora, como a própria palavra exprime, é essencialmente uma função de controle da regularidade do processo e de correção dos seus eventuais defeitos ou desvios do seu rumo, mas na sua essência ela não é 
privativa do juiz no exercício da função jurisdicional, nem é típica de um determinado procedimento. Todo funcionário público, no exercício das suas funções, antes de praticar os atos ou emitir os provimentos inerentes ao seu cargo, tem o dever de verificar se a atividade por ele desempenhada e os atos por ele praticados ou a serem praticados se revestem da indispensável legalidade, regularidade e adequação aos seus fins.

Com isso não quero dizer que, no caso do juiz, essa função não tenha natureza jurisdicional. Trata-se de uma atividade jurisdicional, porque exercida com fundamento no poder jurisdicional dos juízes e porque indispensável para a válida, regular e justa consecução dos fins da jurisdição. Ela não tem existência autônoma, não existe fora do exercício da jurisdição. Mas é uma jurisdição sobre a própria jurisdição.

Por outro lado, apesar de regulada especificamente no procedimento comum do livro II sobre o processo de conhecimento (arts. 342 e 343), ela não é exclusiva de qualquer procedimento específico, porque é uma função de controle permanente que deve ser exercida em qualquer procedimento e em todas as suas fases. A sua concentração ou maior intensidade, após a fase postulatória, por meio de um despacho específico, o despacho saneador, tem como finalidade principal exigir que nesse momento o juiz efetivamente faça uma pausa na condução do processo e se dedique precipuamente à sua ordenação, assegurando assim, que, daí por diante, o processo esteja em ordem e marche com celeridade e determinação em direção ao seu fim, pois, se assim não for, deverá o processo ser extinto, livrando-se o réu do ônus e do constrangimento de ter de defender-se de uma demanda ou de um processo inviáveis.

\section{DESPACHO SANEADOR: ORIGEM E FINALIDADES}

Embora a função de saneamento deva ser permanente, vários sistemas processuais, especialmente no processo de conhecimento de configuração bifásica, têm criado uma decisão interlocutória específica, posicionada entre a fase postulatória e a instrutória, em que se concentra o seu exercício. O legislador brasileiro, desde 1973, tem evitado atribuir-lhe o nome de despacho saneador, que herdamos do direito português, do qual importamos o instituto.

Seguramente influenciado pela audiência preliminar, adotada no Regulamento Judiciário de 1834 do Papa Gregório XVI e no Código austríaco de 1895, foi um Decreto português de 1926 que instituiu o despacho saneador, 
como "uma verdadeira sentença de forma", na expressão de José Alberto dos Reis, para que antes de ingressar na produção das provas, que é a fase do processo "que obriga a maiores despesas e incômodos", sejam resolvidas as questões prévias e prejudiciais, evitando-se que todo esse esforço fosse realizado inutilmente, quando a decisão final esbarrasse na falta de uma condição da ação ou na existência de alguma nulidade intransponível (BUZAID , 1972, p.16-17).

Em 1868, Oskar von Bülow já acentuara que o juiz tem de decidir não só sobre a existência do direito controvertido, mas também, sobre a validade do próprio processo (BÜLOW, 1964, p.6-7). No processo há sempre um dualismo de espécies de questões: as que dizem respeito à res in judicium deducta, ao direito material controvertido, e as que se referem à relação jurídica processual.

Antecedido pelo despacho da inicial, pelas providências preliminares (que podem conduzir à extinção do processo sem resolução do mérito ou ao julgamento antecipado da lide) e, eventualmente, pelo exame de exceções, o despacho saneador é o ponto culminante da série de atos que as partes e o juiz praticam para expungir o processo de quaisquer vícios ou irregularidades, a fim de que, na sua sequência, sejam praticados os demais atos probatórios necessários e seja proferido o julgamento do direito material das partes, com a segurança de que esse resultado será válido e eficaz.

\section{DECISÃO ÚNICA OU MÚLTIPLA}

Alfredo Buzaid (1972, p.33) lecionava que, quanto à forma, o despacho saneador não é necessariamente um só, nem é proferido em um único momento do processo. Pode cindir-se em mais de um pronunciamento, sendo que, todos reunidos, lhe formam a unidade jurídica. Entretanto, analisando a função de saneamento em diversos sistemas processuais contemporâneos, Barbosa Moreira (1989, p.130-131) observa uma tendência à adoção do método concentrado, não de forma radical. A opção se afigura racionalizadora, favorecendo a economia processual, e estimuladora da cooperação entre as partes e o juiz, especialmente se a decisão for adotada em audiência.

O projeto do novo Código de Processo Civil se inclina claramente no sentido de que haja uma decisão interlocutória específica de saneamento do processo, o despacho saneador. Com efeito, o artigo 304 do projeto prevê que o autor poderá até o saneamento do processo, com o consentimento do réu, aditar ou alterar o pedido e a causa de pedir. Também o artigo 363 prescreve 
que suspenderão o processo a carta precatória e a carta rogatória, se requeridas antes da decisão de saneamento. É como se no momento do despacho saneador o juiz fizesse uma pausa no andamento do processo para dedicar-se exclusivamente à função de saneamento que, apesar de instrumental, impõe ao juiz essa atenção especial, porque do seu adequado exercício dependerá o bom êxito na continuidade de um processo hígido e apto a produzir um resultado justo. É boa a opção do projeto, pois isso propicia que todas as questões prévias sejam examinadas em conjunto e que a marcha futura do projeto seja racionalmente planejada, em benefício da celeridade e da segurança jurídica.

Outros dispositivos, entretanto, revelam que a função de saneamento não se esgota em um único ato, podendo desdobrar-se em atos sucessivos, em momentos processuais diferentes. A qualquer tempo pode o juiz determinar o depoimento pessoal das partes (art. 118, VIII), inspecionar pessoas ou coisas (art. 468), assim como examinar a falta de pressupostos processuais ou de condições da ação (art. 472, $\S 3^{\circ}$ ). Podemos concluir sobre esse ponto que o projeto adota o método de saneamento concentrado, mas não radical, ou seja com exceções, que devem encontrar consistentes justificativas, para não frustrar ou enfraquecer a realização dos objetivos do próprio método adotado.

\section{DESPACHO ESCRITO OU DECISÃO EM AUDIÊNCIA}

O Código de 39 introduziu no direito brasileiro o despacho saneador, inspirado nas mesmas razões do Papa Gregório XVI, a saber, a necessidade de expurgar precocemente o processo de vícios, que eram "uma das causas mais importantes de desmoralização do processo e uma das fontes mais abundantes das insídias, surpresas e injustiças em que era tão rico o processo tradicional" (CAMPOS, 1967, p.16). Mas, apesar do entusiasmo demonstrado pelo codificador com a oralidade, esta não se estendia ao saneador, proferido por escrito, pois limitava-se à imediatidade e concentração em audiência dos atos probatórios, das alegações finais e da sentença, estabelecida a identidade física do juiz, consideradas um grande avanço modernizador na época.

O Código de 73 não progrediu na expansão da oralidade. Exaltado como um dos grandes progressos da codificação projetada, a instituição do julgamento conforme o estado do processo, antes do saneador, reduziu a importância deste e procurou evitar o retardamento inútil do desfecho de processos que não dependessem de provas orais. Recuo à oralidade cujos sintomas se expressam igualmente na ampliação da recorribilidade de todas 
as decisões interlocutórias e na redução do alcance da identidade física do juiz (BUZAID, 1967, p.683, 686).

Um novo impulso no fortalecimento da oralidade foi dado pela Lei 8.952/ 94 que, instituindo a audiência de conciliação, cuja denominação foi posteriormente alterada para audiência preliminar (Lei 10.444/2002), determinou que o saneamento do processo fosse cumprido nessa audiência (art. 331, $\S 2^{\circ}$ do Código), presentes as partes ou apenas os seus procuradores ou prepostos.

Cândido Dinamarco, em estudo sobre essa inovação, apontou como sua fonte inspiradora o Código de Processo Civil Tipo para a América Latina e a exaltou pelo "significado intimamente ligado à garantia constitucional do contraditório em sua dimensão moderna voltada à convocação do juiz a participar do processo e dialogar com as partes" (1995, pp.119 e ss). A fixação dos pontos controvertidos, a resolução das questões processuais pendentes e a determinação das provas a serem produzidas seriam adotadas com a participação dos litigantes. O insigne autor chegou a sustentar que a omissão dessa audiência constituiria nulidade absoluta, pois afrouxaria "a imperatividade das leis de ordem pública" e frustraria "os desígnios modernizadores" da reforma (1995, p.124-125).

Os propósitos da reforma não vingaram em plenitude. A prática relativizou a obrigatoriedade da audiência preliminar, dispensando-a não só na hipótese de direitos indisponíveis, mas também na de provável inviabilidade da conciliação, caso em que o saneador poderia ser proferido por escrito, o que foi finalmente consagrado pelas alterações introduzidas no art. 331 por meio da Lei 10.444/ 2002.

O recuo não passou despercebido à crítica lúcida de Cândido Dinamarco, quanto ao prejuízo que dela decorreria, em razão do abandono do saneamento oral, previsto no $\S 2^{\circ}$ do art. 331. Naquela oportunidade o autor revela o retrocesso pelo que ele chama de "má-vontade em aprimorar o sistema processual"' (2003, p.109).

O Projeto de Lei 8.046 de 2010, da Câmara dos Deputados, abandona de vez a possibilidade de saneamento oral, embora mantenha a audiência de conciliação, mas como esta antecederá o prazo de defesa, todos os atos subseqüentes - resposta do réu, providências preliminares e saneamento do processo - serão exclusivamente escritos (art. 342).

Marinoni e Mitidiero (2010, p.121) criticam essa opção, observando corretamente que: 
[...] em um processo de corte cooperativo, o mais adequado, contudo, é que a atividade de organização do processo (sanação de vícios processuais e preparação da prova) ocorra oralmente, em que as partes e o juiz possam dialogar e participar ativamente na definição destas questões.

Há uma evidente perda qualitativa, pelo isolamento do juiz e o abandono do diálogo humano em relação à definição dos rumos do processo, que poderia perfeitamente ser evitada, com o aperfeiçoamento da dinâmica do procedimento ordinário, se o projeto tivesse adotado na jurisdição de conhecimento um verdadeiro procedimento bifásico. Este se caracterizaria pela designação de audiência de conciliação no despacho inicial, devendo a contestação e a réplica serem antecipadamente apresentadas, de modo que, na referida audiência preliminar, frustrada a conciliação e não sendo o caso de julgamento conforme o estado do processo, seguir-se-iam oralmente as atividades de saneamento do processo, deliberadas pelo juiz com a presença e a colaboração das partes. Esse momento de diálogo seria extremamente importante para que o juiz compreendesse com precisão as necessidades probatórias das partes e para que estas, por sua vez, entendendo, na fixação dos pontos controvertidos, quais seriam as questões que o juiz consideraria pendentes de esclarecimento, pudessem direcionar a sua atividade probatória de modo mais eficaz. Considero este último ponto de grande importância. De pouco adianta as partes especificarem as provas, antes da fixação dos pontos controvertidos pelo juiz, porque sobre estes é que a instrução se debruçará ${ }^{1}$.

O saneamento oral também evitaria inevitáveis retardamentos decorrentes da necessidade, corretamente imposta pelo projeto, de que as partes sejam ouvidas sobre as matérias releváveis de ofício (art.10), pois essa oitiva poderia dar-se na própria audiência preliminar. A esse respeito, observe-se que o projeto regulou em artigo próprio (art.343), logo após a disciplina do saneamento, a hipótese, que a parte final do atual art. 327 localiza após a réplica, de correção de defeitos do processo. Situado o novo artigo autônomo nessa posição, nem por isso me parece que deva entender-se que essa regularização deva ser

\footnotetext{
${ }^{1}$ Há inúmeros fatores que impulsionam o juiz brasileiro a preferir os despachos escritos às audiências orais, sendo o principal deles o excesso de trabalho: pautas sobrecarregadas com a paralisação dos processos durante meses, o tempo dispendido com audiências inúteis, em decorrência da ausência de espírito de cooperação das partes e particularmente dos advogados, a quantidade avassaladora de despachos de expediente a serem proferidos, a busca da celeridade a qualquer preço pela pressão superior de atingir metas quantitativas. Com isso ganha a justiça em rapidez e perde em qualidade. Esse modelo precisa ser modificado. Os juízes devem dedicar a maior parte do seu tempo de trabalho às audiências e menos tempo aos despachos e sentenças, e não o contrário.
} 
posterior à decisão de saneamento. Ao contrário, tudo aconselha, inclusive do ponto de vista lógico, que, tal como no Código atual, essa regularização seja promovida no curso das providências preliminares, ou seja, antes do saneamento para que, daí por diante, o processo avance sem vícios, cuja não correção poderá vir a determinar a extinção precoce do processo sem resolução do mérito, evitando-se, assim, a prática sem proveito de atos subseqüentes, especialmente a produção de provas.

\section{CONTEÚDO DO DESPACHO SANEADOR}

O despacho saneador é, ao mesmo tempo, um ato decisório e um ato ordinatório. De acordo com o artigo 342 do Projeto de Lei 8046/2010, integram o conteúdo do saneamento do processo, como ato decisório: a) a solução das questões processuais pendentes; b) a delimitação dos pontos controvertidos sobre os quais incidirá a prova; e c) a especificação dos meios admitidos de produção da prova.

\subsection{A solução das questões pendentes}

O conceito de questão, a meu ver, deve ser bastante abrangente, ou seja, o de qualquer ponto de fato ou de direito sobre o qual deva o juiz pronunciarse em caráter decisório ${ }^{2}$. São questões a concorrência dos pressupostos processuais e das condições da ação, os fatos que as partes alegaram como geradores do seu direito, os elementos jurídicos que compõem os fundamentos do pedido e da defesa e as provas a serem ou não produzidas. Há questões arguídas por uma das partes e impugnadas pela outra, há questões arguídas por uma e não impugnadas pela outra e há questões não arguídas sobre as quais o juiz deve pronunciar-se de ofício.

A redação do art. 343 do projeto inclui como conteúdo do saneador a decisão das questões processuais pendentes. De início, cumpre observar o aprimoramento do texto em relação ao do $\S 2^{\circ}$ do art. 331 do Código vigente, antecedendo esse ponto em relação à fixação dos fatos controvertidos, pois logicamente essa fixação somente ocorrerá se o processo estiver em ordem

\footnotetext{
${ }^{2}$ Procedente a crítica de Heitor Sica (ob. cit., pp.185-188) ao tradicional conceito de questão, inspirado em Carnelutti, como "ponto controvertido de fato ou de direito", porque há diversas matérias que o juiz deve apreciar no processo, independentemente de terem sido controvertidas e até mesmo de terem sido alegadas por quaisquer das partes.
} 
para prosseguir, tendo sido rejeitadas todas as preliminares que pudessem determinar a sua imediata extinção. Todavia a expressão (questões processuais pendentes), que é a mesma do Código atual, não representa com fidelidade toda a extensão da cognição que o juiz deve exercer nesse momento a respeito das questões processuais. Não se trata apenas de examinar as questões pendentes, ou seja, aquelas que as partes suscitaram ou que, porventura, o próprio juiz, de ofício, tenha submetido às partes por força dos arts. 10 e 343. Deve o juiz nesse momento resolver conclusivamente se o processo está em condições de prosseguir validamente. Para esse fim, o juiz deve examinar, ainda que não suscitadas, a concorrência das condições da ação, bem como de todos os pressupostos processuais cuja ausência possa ocasionar nulidade absoluta, além de todas as demais questões processuais arguídas pelas partes. Deve também, de ofício ou a requerimento de qualquer das partes, corrigir quaisquer irregularidades e erros materiais.

Quanto às condições da ação, observe-se que o projeto não faz qualquer menção à possibilidade jurídica (v. arts. 327, XI, e 472, VI), parecendo inclinarse no sentido de considerá-la matéria de mérito. Penso, entretanto, que a referida condição sobreviverá, no âmbito do interesse de agir, para facultar ao juiz repelir prima facie demandas sem qualquer viabilidade jurídica, independentemente de cognição exaustiva e, portanto, sem definitiva resolução de mérito e sem coisa julgada (GRECO, 2011, p.203-206).

Quanto aos pressupostos processuais, cabe fazer algumas distinções. Adotada uma definição bastante ampla dessa categoria para abranger "todos os requisitos que devem ser observados no processo, desde o ato introdutório até o seu desfecho" (GRECO, 2011, p.275), caberá ao saneador verificar a concorrência dos pressupostos de validade e de regularidade dos atos praticados até a sua prolação, assim como daqueles que devem verificar-se durante todo o curso da relação processual, como a competência absoluta do juízo (art.64, § $1^{\circ}$, do projeto). Os pressupostos relativos aos atos subsequentes deverão ser objeto da atenção do juiz no momento em que esses atos forem praticados ou assim que cheguem ao seu conhecimento. O controle dos pressupostos processuais cuja inobservância acarrete nulidade absoluta, ou seja, das questões de ordem pública, assim como das irregularidades e dos erros materiais, será exercido de ofício pelo juiz. Já o controle dos pressupostos cuja falta acarrete nulidade relativa dependerá da alegação do interessado na primeira oportunidade em que falar nos autos e da verificação de prejuízo (arts. 252, 253, 257, $\S 1^{\circ}$, e 258, par. único, do projeto). Parece-me que devam ser consideradas questões 
de ordem pública as que estabelecem de modo imperativo a observância de determinado requisito para assegurar o respeito a interesse público precisamente determinado, a direitos fundamentais e a princípios do devido processo legal, quando indisponíveis pelas partes (GRECO, 2011, p.336, 337) ${ }^{3}$. Os defeitos de forma não constituem necessariamente nulidades absolutas. Conforme observa judiciosamente Carlos Alberto Alvaro de Oliveira (2009, p.245-249), a forma não tem, em si mesma, valor próprio, pois se trata de um meio para atingir determinado fim. Se o ato, por outra forma, atingiu a sua finalidade e o respeito à forma não se impunha de modo obrigatório como exigência de um interesse público precisamente determinado, de garantia a direitos fundamentais ou a princípios indisponíveis do devido processo legal, não haverá nulidade absoluta a ser apreciada de ofício pelo juiz.

Deverá também o magistrado decidir sobre a admissão das provas, a expedição de cartas precatórias ou rogatórias, a expedição de ofícios e diligências, eventual dilatação de prazos processuais e a alteração da ordem em que devam ser produzidos os meios de prova (art. 118, V), mas essas são questões que dizem respeito ao planejamento e à organização da fase subsequente, que deverão ser decididas depois da fixação dos pontos controvertidos.

Mas não são apenas as questões processuais que o juiz deve apreciar no despacho saneador. Deve ele também proferir decisão sobre as questões de direito material anteriormente suscitadas no âmbito das tutelas da urgência e da evidência e que não tenham sido anteriormente solucionadas. São tutelas incidentes que não devem aguardar a sentença final. Na tutela da urgência é o periculum in mora que impõe a sua rápida solução. Na tutela da evidência é a mais ampla proteção do direito subjetivo material que exige a sua antecipação, sob pena de frustrar-se o objetivo do instituto. Ambas podem ter sido decididas liminarmente ou logo após a contestação do réu. Se não o foram, o saneador é o seu desfecho natural. Sobre a possibilidade de exame nesse momento de outras questões de direito material, teceremos comentários mais adiante.

\footnotetext{
${ }^{3}$ Nessa oportunidade mencionei, entre os princípios indisponíveis: a independência, a imparcialidade e a competência absoluta do juiz; a capacidade das partes; a liberdade de acesso à tutela jurisdicional em igualdade de condições por todos os cidadãos (igualdade de oportunidades e de meios de defesa); um procedimento previsível, equitativo, contraditório e público; a concorrência das condições da ação; a delimitação do objeto litigioso; o respeito ao princípio da iniciativa das partes e ao princípio da congruência; a conservação do conteúdo dos atos processuais; a possibilidade de ampla e oportuna utilização de todos os meios de defesa, inclusive a defesa técnica e a auto-defesa; a intervenção do Ministério Público nas causas que versam sobre direitos indisponíveis, as de curador especial ou de curador à lide; o controle da legalidade e causalidade das decisões judiciais através da fundamentação; uma cognição adequada pelo juiz e, em certos limites, a celeridade do processo.
} 


\subsection{Delimitação dos pontos controvertidos}

Originária do questionário do direito português, hoje substituída pela já citada seleção da matéria de fato, a delimitação dos pontos controvertidos, resultantes das proposições fáticas das partes e das provas preconstituídas já produzidas, tem a inquestionável finalidade de orientar a admissão e a produção das provas.

A natureza fática dos pontos controvertidos está corretamente disposta no art. 342 que, em redação melhor do que a do Código atual, menciona a delimitação dos "pontos controvertidos sobre os quais incidirá a prova", ou seja, das proposições ou enunciados fáticos a respeito dos quais versará a subsequente instrução probatória. Na medida em que o direito possa ser objeto de prova, como o direito estrangeiro, local ou costumeiro (art.362), também poderá integrar o conteúdo da fixação dos pontos controvertidos.

Para atingir com proveito a finalidade de orientar a admissão e a produção das provas, seria fundamental que fosse decidida em audiência oral, o que o art. 342 do projeto não determina, para que o diálogo cooperativo permitisse às partes darem a conhecer ao juiz as suas perspectivas probatórias, bem como a utilidade das provas por elas requeridas e compreender a perspectiva probatória do juiz e as provas que possam auxiliá-lo. Não pode ser uma atividade puramente burocrática, que obrigue o juiz a proferir o conhecido despacho ordinatório solicitando que as partes especifiquem as provas que pretendem produzir, porque estas fizeram um protesto genérico por provas absolutamente impreciso, já que nem elas sabem exatamente o que de fato terão necessidade de provar, muito menos o juiz.

Ocorre que, mesmo após esse despacho, muitas vezes as partes continuam sem saber de que provas efetivamente necessitarão, limitando-se a insistir em prova oral e documental supervenientes, que nem mesmo estão seguras de que irão produzir. Assim, aquilo que Buzaid pretendia evitar, quando criou no Código o julgamento conforme o estado do processo, acaba acontecendo: o retardamento do desfecho do processo para aguardar uma audiência de instrução e julgamento em que nenhuma prova útil será produzida.

A bem da verdade, é forçoso reconhecer que o projeto não exclui a audiência oral das partes na deliberação sobre os pontos controvertidos. $\mathrm{O}$ inciso VIII do art. 118 confere ao juiz o poder de "determinar, a qualquer tempo, o comparecimento pessoal das partes, para ouvi-las sobre os fatos da causa, caso em que não incidirá a pena de confesso". No contexto dos poderes do juiz, 
esse dispositivo soa como uma simples faculdade, não necessariamente vinculada à fixação dos pontos controvertidos e ao momento do saneador. Se, conforme já relatado, a cultura burocrática do juiz brasileiro o impulsionou a dispensar a audiência preliminar quando ela era por sã doutrina considerada obrigatória, muito menos força terá esse dispositivo de convencer o juiz a realizar uma audiência oral para a delimitação dos pontos controvertidos.

A delimitação dos pontos controvertidos não é simplesmente a enumeração dos fatos ou proposições fáticas sobre os quais divergem as partes, mas apenas daqueles que ainda não restaram esclarecidos pela prova documental já produzida. A identificação desses pontos duvidosos, tanto nas perspectivas das partes quanto na do juiz, é que vai determinar a admissão das provas a serem produzidas. A tolerância deve ser o critério dessa delimitação. O Código português oferece, nesse aspecto, uma proveitosa lição, estatuindo (art. 511.1) que "o juiz, ao fixar a base instrutória, selecciona a matéria de facto relevante para a decisão da causa, segundo as várias soluções plausíveis da questão de direito, que deva considerar-se controvertida". No direito espanhol, o dispositivo referido no parágrafo anterior ensejou o comentário de Banacloche Palao de que não é razoável que o tribunal repute incontroverso fato que qualquer das partes considere controvertido, cerceando assim que seja devidamente esclarecido na instrução probatória (In BANACLOCHE PALAO, Julio et alii, 2009, p.319). A constatação da inexistência de matéria fática a ser elucidada propiciará, por outro lado, a aceleração do julgamento conforme o estado do processo, dispensando o próprio despacho saneador.

Cândido Dinamarco (1995, p.132-133) atribui a essa fixação o caráter de um ato meramente ordinatório, não propriamente decisório. Prefiro reconhecer-lhe natureza decisória, mas sem daí extrair qualquer consequência restritiva de eventual produção de provas sobre outros pontos, nesse momento não relacionados, pois a dinâmica do processo e o conteúdo das provas futuras podem evidenciar outras circunstâncias duvidosas, cujo esclarecimento se torne necessário. Também nesse ponto, a experiência portuguesa pode ajudar-nos. Ali, a condensação dos fatos incontroversos não é considerada definitiva, mas a seleção dos fatos a serem provados tem valor definitivo no sentido positivo, não no sentido negativo. Isso significa que, sem prejuízo de eventual questionamento ulterior por ocasião do recurso contra a sentença final (Projeto, art.963, parágrafo único), a prova poderá versar sobre outros pontos não relacionados nesse momento pelo juiz, mas não poderá o juiz dispensar a que foi deferida para esclarecer fatos já considerados controvertidos, ainda que 
posteriormente o juiz modifique o seu entendimento quanto à existência de controvérsia (BAPTISTA, 2006, p.414-415). E se o juiz omitir a fixação dos pontos controvertidos, o que infelizmente acontece, certamente essa omissão, exceto nos casos mais simples, poderá ter reflexo negativo na instrução probatória, podendo determinar a nulidade do processo a partir do saneador, se alegada na primeira oportunidade e comprovado o prejuízo.

O diálogo entre as partes e o juiz seria também de suma importância, para que as partes pudessem preparar-se para a extensão da coisa julgada à apreciação das questões prejudiciais, prevista no artigo 490 do projeto, alertando-as o julgador para a necessidade de atuação vigorosa no esclarecimento dos enunciados fáticos de que possam resultar essas questões prejudiciais, tendo em vista o alcance extra-processsual que adotará a decisão que as apreciar.

\section{3. Admissão dos meios de prova}

$\mathrm{O}$ art. 342, em redação que me parece inadequada, inclui no conteúdo decisório do saneamento do processo a especificação dos meios admitidos de produção das provas. Ora, os meios de prova são apenas os tipos de fontes que podem transmitir o conteúdo dos fatos ao conhecimento do juiz e das partes, a saber, os meios legalmente previstos (confissão, prova documental, prova testemunhal, prova pericial, presunções e indícios e inspeção judicial) e eventualmente outros tipos de elementos probatórios não previstos em lei. Todavia, inúmeros dispositivos do projeto evidenciam que não é somente isso que o juiz decide no saneador, mas que, ao contrário, lhe compete deliberar concretamente sobre as provas a serem produzidas, e não apenas sobre os meios que lhes correspondem. Assim, por exemplo, os arts. 293, VI, 296, e 325, parágrafo único, explicitam que as partes indicam, propõem ou especificam as provas concretas que pretendem produzir, cabendo ao juiz, nos termos do art. 354, determinar as que forem necessárias (ou também úteis, faltou dizer), inclusive nomeando perito e fixando o prazo para entrega do laudo, se for o caso (art. 450). O saneador é, portanto, o ato em que se concentra a admissão de quase todas as provas, especialmente as requeridas pelas partes. Depois dele, somente em casos excepcionais, como o de fatos supervenientes (art. 330), terão as partes o direito de propor a produção de novas provas. Entretanto, a qualquer tempo poderá o julgador ex-officio determiná-las (arts. 118, VIII, e 354). 


\section{IMPULSO PROCESSUAL NO DESPACHO SANEADOR}

A admissão das provas a serem produzidas implica necessariamente na determinação dos atos subsequentes a serem praticados para que essa produção se efetive. Assim, é indissociável dessa última parte do conteúdo do saneador o impulso oficial do processo em direção ao seu desfecho final. Na redação original do Código de 73 essa função de impulso do saneador era evidenciada pela obrigatória designação da audiência de instrução e julgamento. A partir da criação da audiência de conciliação, essa designação deixou de ser obrigatória, pois o legislador estabeleceu que o juiz a designaria no saneador, somente nos casos em que a considerasse necessária. Esta regra está reproduzida no artigo 342 do Projeto 8046/2010. Se o juiz tiver deferido prova oral, certamente será conveniente, desde logo, designar a audiência final de instrução e julgamento. Entretanto, se a prova deferida tiver sido apenas a pericial e a documental, talvez a audiência não venha a afigurar-se necessária, podendo o juiz postergar a decisão sobre a sua designação para momento posterior à produção dessas provas.

Inovação do projeto, que diz respeito ao impulso e que, a meu ver deve ser tratada no saneador, é a constante do inciso V do artigo 118, que confere ao juiz o poder de "alterar a ordem de produção dos meios de prova, adequando-os às necessidades do conflito, de modo a conferir maior efetividade à tutela do bem jurídico", fora das hipóteses de produção antecipada de provas (arts. 367 a 369). Essa disposição foi introduzida no projeto em substituição à flexibilização procedimental prevista nos artigos 107, V, e 151, § $1^{\circ}$, do projeto original.

Reduziu-se a flexibilização procedimental à alteração da ordem de produção dos meios de prova. A meu ver, a nova determinação tem três efeitos. O primeiro é o de permitir que a tomada do depoimento oral das partes ou das testemunhas ocorra antes da produção da prova pericial, independentemente da urgência. Pode evidenciar-se conveniente apurar mais detidamente os fatos, antes de submetê-los ao exame pericial. Nesse caso, deverá o juiz esclarecer se a convocação sujeita ou não à parte à pena de confissão, em caso de não comparecimento ou de recusa de depor (art. 371, $\S 1^{\circ}$, do projeto), tendo em vista o já comentado inciso VIII do art. 118.

O segundo é o de permitir que, na audiência, seja alterada a ordem dos depoimentos: primeiro os das testemunhas e depois os das partes ou dos peritos; ou antes as testemunhas do réu e depois as do autor. Ou até mesclar as testemunhas de um e de outro. 
O terceiro é propiciar a fragmentação da instrução probatória, colhendo inicialmente as provas sobre determinada questão prévia, preliminar ou prejudicial, para desde logo decidi-la em sentença parcial, e postergando a produção das demais provas para momento subsequente.

Parece-me que essa flexibilização seria mais apropriada se o saneador fosse proferido em audiência, pois resultaria do diálogo do juiz com as partes. De qualquer modo, impõe-se que essa alteração da ordem procedimental seja adotada em decisão fundamentada. Tudo aconselha que isso ocorra no saneador, que é o momento em que o juiz deve planejar toda a sequência da fase probatória subsequente.

\section{A PRECLUSÃO NO DESPACHO SANEADOR}

Se o ordenamento processual estabelece um momento próprio para que o juiz exerça a atividade de saneamento, como meio de organizar a marcha do processo e expungi-lo de vícios e irregularidades, parece inevitável que essa atividade imponha, em alguma medida, um regime de preclusões.

Para Chiovenda (1965, p.156), as preclusões compreendiam todos os casos em que ocorresse perda, extinção ou consumação de uma faculdade processual. Às preclusões está associada a idéia de perda por ter sido ultrapassado o limite para o exercício de faculdades processuais (THEODORO JÚNIOR, 2000, p.6), havendo dois grandes campos dos atos processuais a que elas se aplicam: o dos atos das partes e o das decisões do juiz a respeito de determinadas questões, que ficam proibidos em razão da preclusão. Interessanos aqui, particularmente, o segundo campo, ou seja, a limitação que as preclusões impõem à apreciação ou ao reexame pelo juiz de determinadas questões.

Os fundamentos das preclusões para o juiz se encontram na necessidade de alcançar rapidamente o resultado final do processo e de oferecer às partes segurança jurídica quanto à preservação dos efeitos das questões já decididas e à previsibilidade dos limites em que os poderes decisórios ainda incidirão no processo (CHIOVENDA, Giuseppe in SICA, p.181 e 305). É inerente à idéia de processo uma sequência de atos encadeados direcionados para alcançar um fim. Se as questões decididas no seu curso puderem sempre sofrer reexame, o processo a todo momento estará sendo desviado do seu rumo, com inevitável retardamento da obtenção do seu resultado, a surpresa e a frustração das expectativas das partes. 
Além disso, das decisões das questões processuais sempre as partes, ou uma delas, podem extrair algum direito subjetivo que deve ser respeitado no seu curso, salvo se eivadas de alguma nulidade irremediável, podendo ser sustentado o esgotamento do poder jurisdicional do julgador (THEODORO JÚNIOR, 2000, p.14-15).

As matérias decididas no saneador devem, portanto, gozar de preponderante estabilidade para assegurar a organizada e permanente continuidade do processo em direção ao seu fim, sem retrocessos que ensejem a ressurreição de questões já decididas e o conseqüente retardamento da prestação jurisdicional final.

Liebman assinalava que o direito brasileiro havia herdado do processo comum medieval a observância de uma "ordem legal necessária das atividades processuais", que compartimentava o procedimento em uma série fixa de etapas sucessivas por meio das preclusões. Para isso, o saneador deveria precluir qualquer discussão sobre a validade ou regularidade do processo e dos atos processuais, ressalvadas as questões que o juiz pudesse decidir de ofício. E o grande mestre associava essa preclusão para o juiz à adoção pelo direito brasileiro do princípio da eventualidade, que obrigava o réu a concentrar em um só momento todas as matérias de defesa, mantido no projeto no art. 330 (LIEBMAN in Chiovenda, 1965, p.158-160). A análise do mestre baseava-se no saneador criado no século XX, já como consequência da tendência à implementação de um processo bifásico (De Santis, 2004, p.1260). Todavia, como já verificamos anteriormente, essa não era a tradição do direito brasileiro que, desde as Ordenações Afonsinas, havia munido o juiz do amplo poder de revisão de todas as suas decisões interlocutórias. Essa maleabilidade sempre encontrou suporte na necessidade de corrigir erros in procedendo e erros in judicando (MESQUITA In ASSIS, 2007, p.1523). Na vigência dos Códigos de 39 e de 73, a doutrina e a jurisprudência não se pacificaram, variando as opiniões entre dois pontos extremos, o da absoluta proibição de reexame pelo juiz da decisão de qualquer questão já decidida, até a mais ampla possibilidade desse reexame até a sentença final, com inúmeras opiniões intermediárias. O Supremo Tribunal Federal consagrou na Súmula $n^{0} 424$ da sua Jurisprudência Predominante, que "transita em julgado o despacho saneador de que não houve recurso, excluídas as questões deixadas, implícita ou explicitamente, para a sentença". Alfredo Buzaid, como Ministro da Corte Suprema, relatou em 1984 julgado em que sustentou a inaplicabilidade desse enunciado à falta de condições 
da ação, de pressupostos processuais, à litispendência, à coisa julgada e à perempção (AgRg no Ag 95.837/GO, DJU 08.06.1984, p.9259) (MESQUITA in ASSIS, 2007, p.1526).

Se o art. 492 do projeto, repetindo o art. 471 do Código de 1973, pode dar a impressão de que qualquer questão apreciada pelo juiz no curso do processo deva ficar acobertada pela chamada preclusão consumativa, não podendo mais ser reexaminada pelo próprio juiz, em realidade, o que resulta da lição de Buzaid é que, ainda que em muitos casos os sistemas processuais procurem dar essa estabilidade a tais decisões e que, como regra, seja ela desejável, deve ela ser excluída categoricamente nas questões de ordem pública, porque, como observa Humberto Theodoro Júnior, a chamada preclusão pro iudicato "veda ao juiz reapreciar o que já decidiu em torno da matéria disponível pelos litigantes. Não aquilo que diga respeito à ordem pública", "pois aquilo que diz respeito à legitimidade e eficácia da própria função jurisdicional tem de ser aferido sempre enquanto não proferida a decisão de mérito (CPC, art. 267, § $3^{\circ}$ )" (THEODORO JÚNIOR, 2000, p.17) ${ }^{4}$.

Além dessa regra geral, a questão das preclusões no saneador deve ser analisada em uma série de situações que suscitam dúvidas e que tentaremos equacionar a seguir, com particular atenção sobre as disposições do projeto de Código ora em tramitação na Câmara dos Deputados.

\section{1. As questões não apreciadas no saneador}

Era e ainda é corriqueiro o juiz considerar a falta de uma condição da ação, como a legitimidade, intrincada com o mérito, relegando-a para apreciação na sentença final. A meu ver, esse tipo de postergação, além do comodismo, a que já tenho feito referência, resulta da inexata compreensão por parte do julgador da distinção entre condições da ação e mérito. Apesar de o exame daquelas ter de efetuar-se à luz do direito material, pela teoria da asserção não o é com base no direito material provado, mas simplesmente alegado pelo autor. Se a hipótese proposta pelo autor o habilita em tese a possuir as condições da ação, isto basta para caracterizá-las. Se o réu contesta a hipótese apresentada pelo autor, a questão não é mais de falta de condição da ação, mas de existência ou inexistência do direito do autor e, portanto, questão de mérito.

${ }^{4} \mathrm{O}$ dispositivo do Código de 73 citado corresponde ao $\S 3^{\circ}$ do art. 472 do projeto. 
O dever do juiz de examinar no saneador praticamente todas as preliminares processuais decorre, de um lado, da natureza indisponível ou de ordem pública de grande parte dessas matérias, como a litispendência, a coisa julgada e a falta de condições da ação. O projeto, no art. 118, IX, atribui ao juiz o dever de "determinar o suprimento de pressupostos processuais e o saneamento de outras nulidades". E, no art. $472, \S 3^{\circ}$, reitera a regra do atual $\S 3^{\circ}$ do art. 267, que determina a sua apreciação de ofício da falta de pressupostos processuais e de condições da ação, da litispendência, da coisa julgada e da perempção. Já tive oportunidade de observar que esse dispositivo vai longe demais, porque há pressupostos processuais cuja falta constitui mera nulidade relativa, como a incompetência relativa, que normalmente o juiz não pode apreciar de ofício (GRECO, 2011, p.276, 335). Todavia, os pressupostos processuais, cuja falta caracterize nulidade absoluta, como a incompetência absoluta, o impedimento do juiz, a inadequação do procedimento sumário ou especial, ao lado da litispendência, da coisa julgada, da perempção e da falta de condições da ação, o juiz deve apreciar no saneador, se não o tiver feito anteriormente, porque a validade do processo é sempre uma questão pendente, ainda que não arguída por qualquer interessado. Ou seja, o despacho saneador é o momento culminante adequado para apreciação pelo juiz das nulidades absolutas, da falta de condições da ação, das nulidades relativas arguídas pelo interessado, assim como das proposições de provas, dos requerimentos de dilação de prazos e de alteração da ordem de produção das provas (projeto, art. 118, V), e ainda dos requerimentos de diligências e de expedição de cartas precatórias e rogatórias (art. 363); enfim, de todos os pressupostos, exceto aqueles que eventualmente a lei estabeleça que sejam julgados em decisões próprias. Esse dever resulta, de um lado, do princípio de que toda autoridade pública tem de velar pela legalidade da sua atividade; e, de outro, do direito subjetivo do réu de livrar-se, o quanto antes, de uma demanda manifestamente injusta que, por si só, lhe impõe o ônus de ter de defender-se e de suportar restrições ao pleno gozo do seu direito.

José Alberto dos Reis condenava com severidade as decisões que no saneador deixam de apreciar matérias de ordem pública ou outras quaisquer requeridas ou propostas pelas partes, condenando-as de inertes e cômodas. Mas o Autor reconhecia que muitas vezes a solução de uma dessas questões poderia depender da apuração de certos fatos ainda não esclarecidos, o que tornaria absolutamente impossível que o juiz as resolvesse no saneador (REIS, 1981, p.185). 
Examinemos algumas hipóteses. A primeira é a da decisão que, tendo a questão processual sido suscitada pela parte, explicitamente a relega para exame na sentença. Se a questão é a falta de uma condição da ação, a sua concorrência é um requisito de validade do julgamento de mérito, não de validade do processo. Se o mérito não foi antecipadamente decidido, mas o será apenas na sentença final, deve poder o réu rebelar-se desde logo contra a não apreciação da falta de condição da ação no saneador, para livrar-se do ônus a que está sendo injustamente submetido de se defender e de ter reduzido o pleno gozo do bem questionado pela demanda injusta. O projeto (art.969) não institui agravo de instrumento para impugnação desse tipo de pronunciamento do juiz. Assim, parece-me que a via de impugnação adequada da postergação, não propriamente recursal, como ato de autoridade eivado de ilegalidade, no regime do Projeto, seria o mandado de segurança.

Já a concorrência dos pressupostos de validade do processo como um todo, subjetivos e objetivos (competência absoluta e imparcialidade do juiz, capacidade das partes, litispendência, coisa julgada, perempção) deve verificarse em todos os atos e fases do processo. E os pressupostos específicos de determinados atos devem verificar-se no momento em que forem praticados. Nem uns, nem outros, podem ter a sua apreciação relegada para a sentença final, pois isso subverteria a ordem natural dos atos do processo, a menos que se trate de algum pressuposto específico da própria sentença final, como, por exemplo, se uma das partes requereu que somente a sentença final fosse proferida em segredo de justiça. Se o juiz relegar para a sentença final o exame de pressupostos processuais comuns ou específicos de atos do processo anteriores à sentença, estará criando grande insegurança jurídica e dando continuidade à prática de atos que poderão ser absolutamente inúteis, tendo de ser renovados, se incompatíveis com o que vier a ser decidido a respeito do mencionado pressuposto. No mesmo grau de jurisdição, não pode haver decisão interlocutória condicional, nem atos processuais condicionais, como não pode haver sentença condicional (art. 479, parágrafo único do projeto), a não ser no âmbito da tutela da urgência ou da evidência. Carnelutti foi categórico, na sua clássica obra sobre a teoria dos atos processuais. Em todos os provimentos, há de negar-se a possibilidade de que a sua eficácia fique submetida a uma condição voluntária. Um ato processual que fique vinculado a uma condição deve ser considerado nulo (CARNELUTTI, 1944, p.542-543). A sujeição da validade de um ato processual a evento futuro e incerto somente pode decorrer da lei ou da intervenção de uma instância superior, como ocorre, por exemplo, no incidente 
de recursos extraordinário e especial repetitivos (arts. 990 e 995 do projeto).Também José Alberto dos Reis critica o julgamento provisório e sob reserva a respeito da legitimidade das partes (1981, p.186). O mesmo acontece com a proposição de provas, com a dilatação de prazos, com a alteração da ordem de produção dos meios de prova ou com a solução de requerimentos de diligências. A boa e segura marcha do procedimento em direção ao seu fim interessa a todos, juiz e partes, porque confere segurança e previsibilidade às condutas de todos os sujeitos do processo ${ }^{5}$. No caso de nulidades absolutas já ocorridas e não remediadas pelo saneador omisso, inválido será o processo desde esse momento, podendo essa nulidade retroagir, se existente, desde momento anterior ao próprio saneador. Ainda que cabível agravo de instrumento contra tal saneador, como, por exemplo, na hipótese de tratar-se de questão de exclusão de litisconsorte por ilegitimidade (art. 969, VII), a postergação não preclui se não interposto tal recurso, podendo ser de ofício reexaminada, a qualquer tempo. Afasta-se a incidência do art. 492 às nulidades mais graves. Se se tratar de nulidade relativa, arguída oportunamente pela parte interessada, a postergação do seu exame não precluirá, se não previsto agravo sobre tal matéria, mas precluirá, se previsto e não interposto. Em qualquer caso, poderão tais questões ser reexaminadas pelo juiz em razão de fatos ou de direitos supervenientes.

Nas omissões puras, ou seja, no simples silêncio do saneador a respeito de matérias sobre as quais deveria ter-se pronunciado, a saber, matérias releváveis de ofício e aquelas que foram explicitamente submetidas pelas partes ao juiz, cumpre apurar, em primeiro lugar, se não foram elas implicitamente decididas pelo saneador como um todo. Parece-me que se o réu expressamente arguiu a questão na contestação e o juiz declarou saneado o processo, deve reputar-se rejeitada a preliminar por tal decisão. A possibilidade de reexame posterior dessa decisão dependerá, para o próprio juiz, de tratar-se de matéria de ordem pública. Se não houve arguição de qualquer das partes, ainda que se trate de matéria de ordem pública, que incumbia ao juiz examinar de ofício, não se pode ver caracterizado o indeferimento implícito pela simples omissão. É a solução do código português no art. $510^{\circ}$, já citado. Botelho de Mesquita noticia que, não obstante a Súmula 424, o Supremo Tribunal Federal adotara o entendimento de que "não se pode considerar matéria preclusa matéria não

\footnotetext{
${ }^{5}$ Acima, quando tentamos delimitar o âmbito das nulidades absolutas, incluímos na enumeração dos princípios imperativos do processo civil (nota 21) um procedimento previsível, equitativo, contraditório e público.
} 
decidida" (2007, p.1527). Não é razoável presumir que o juiz tenha exercido cognição sobre todas as matérias que lhe incumba examinar de ofício, se ninguém o alertou para a ocorrência de uma nulidade absoluta.

\subsection{As decisões não imediatamente recorríveis}

$\mathrm{O}$ art. 492 do projeto reitera a regra, constante do atual art. 471, de que nenhum juiz decidirá novamente as questões já decididas relativas à mesma lide. Estou interpretando esse dispositivo em consonância com a doutrina mais acatada, traduzida no voto de Alfredo Buzaid acima referido, segundo o qual esse dispositivo não se aplicaria às matérias de ordem pública ${ }^{6}$, assim como a fatos ou direitos supervenientes, que poderiam provocar a reapreciação de questões anteriormente decididas, pelo mesmo juiz antes da sentença final ou nela mesma. Entretanto, o projeto não contém disposição expressa que preveja essa reapreciação. No art. 963, parágrafo único, limita-se a dispor que "as questões resolvidas na fase cognitiva, se a decisão a seu respeito não comportar agravo de instrumento, não ficam cobertas pela preclusão e devem ser suscitadas em preliminar de apelação, eventualmente interposta contra a decisão final, ou nas contrarrazões." Por esse dispositivo, poder-se-ia supor que inexistiria preclusão para o reexame de ofício dessas questões apenas pelo tribunal a que estiver submetido o juiz em grau de recurso, o que não significaria necessariamente que a igual preclusão não estivesse sujeito o próprio juiz de primeiro grau. A meu ver, esse entendimento, que é adotado pela atual legislação espanhola ${ }^{7}$, entre nós não se sustenta, porque imporia ao juiz o dever de praticar conscientemente no processo atos absolutamente nulos, pois a nulidade dos atos antecedentes contamina os consequentes (art. 256 do projeto), desvirtuando o sentido teleológico que deve inspirar a sua conduta, na expectativa de que algum prejudicado viesse a final a recorrer da sentença para obter a anulação de todo o processo, quando está ao seu alcance desde logo regularizá-lo e redirecioná-lo de modo adequado para que, com a maior rapidez e economia, atinja a sua finalidade.

Marinoni e Mitidiero (2010, p.122) incluem no saneador a decisão sobre a inversão ou a dinamização do ônus da prova. Trata-se de decisão irrecorrível, prevista no art. 358 do projeto que, em minha opinião, integra o rol das questões

\footnotetext{
${ }^{6}$ V. ROCHA, Raquel Heck Mariano da, ob. cit., pp.128-129.

${ }^{7}$ V. art. 207 da Ley de Enjuiciamiento Civil.
} 
de ordem pública, porque diz respeito à paridade de armas e à plenitude de defesa, que a qualquer tempo poderá ser objeto de revisão pelo juiz.

Quanto às questões que não são de ordem pública, como nulidades relativas, se sobre elas se pronunciou o juiz em decisão interlocutória como o saneador, após terem sido regularmente suscitadas pela parte interessada, ficarão preclusas se não impugnadas por $\operatorname{agravo}^{8}$ e, se não houver recurso cabível, ficarão preclusas para o juízo de primeiro grau, mas não para o tribunal, se renovadas como preliminares de futura apelação (art. 963, parágrafo único). Esse será o alcance da disposição do art. 492 do projeto. Entretanto, é preciso sempre fazer a ressalva de que o juiz de primeiro grau sempre pode rever a sua decisão, na medida em que for omissa, obscura ou contraditória, até mesmo para modificá-la, se o prejudicado tiver interposto embargos de declaração, com fundamento no art. 976 do projeto.

\subsection{A preclusão no deferimento ou indeferimento de provas}

Já mencionamos que um dos elementos do despacho saneador consiste na admissão das provas propostas pelas partes ou determinadas de ofício pelo juiz. Normalmente, a prova pericial, a prova testemunhal e os depoimentos pessoais das partes são deferidos no saneador. $\mathrm{O}$ deferimento de provas no saneador ocorre porque o juiz reconhece que há controvérsia sobre a verdade fática, cujo esclarecimento é imperioso para o julgamento da causa. Pode o juiz nesse momento deferir ou determinar apenas algumas provas e não outras. Isso não o impedirá de posteriormente, em qualquer momento do processo, vir a deferir ou determinar de ofício a produção de provas que indeferiu no saneador, com fundamento no art. 354 do projeto. Não há, portanto, preclusão para o juiz, que o impeça de determinar posteriormente a produção de outras provas, além das que deferiu ou determinou no saneador.

Entretanto, não me parece que o juiz, que no saneador deferiu uma determinada prova, possa posteriormente rever esse deferimento, dispensando a produção de prova já admitida. A avaliação da necessidade ou utilidade da prova no momento da sua admissão não permite que a prova seja posteriormente

\footnotetext{
${ }_{8}^{8}$ Parece-me que a essas questões, decididas com recurso cabível, mas não interposto, se referiu Humberto Theodoro Júnior quando afirmou: "se a questão decidida, sem recurso da parte, envolvia matéria disponível, haverá preclusão, não podendo o tema ser reapreciado (ex.: requerimento de prova denegado, cerceamento de defesa, pedido de devolução de prazo por embaraço judicial não acolhido etc." (ob. cit., p.18). No sistema do projeto em exame nenhuma dessas decisões é recorrível, daí se extraindo a conclusão adotada acima de que haverá preclusão para o juiz de primeiro grau, mas não para o tribunal por ocasião do julgamento da apelação.
}

SCIENTIA IURIS, Londrina, v.16, n.1, p.83-112, jul.2012 
dispensada no mesmo grau de jurisdição, porque isso violaria o direito da parte de defender-se provando ${ }^{9}$, a não ser se o sujeito, que a requereu, abrir mão da sua produção ou, no caso de não comparecimento da testemunha que a parte se comprometeu a levar à audiência independentemente de intimação (art. 441, $\S 2^{\circ}$, do projeto). Observe-se que o projeto, a meu ver corretamente, não reproduziu a regra da parte final do parágrafo único do art. 407 do Código vigente, que permite ao juiz dispensar testemunhas se a parte tiver arrolado mais de três para a prova de cada fato. Não pode também o juiz, depois de deferida determinada prova, dispensá-la porque entendeu que outra já comprovou suficientemente determinado fato. A parte que teve deferida prova por ela requerida tem, a meu ver, direito adquirido a produzi-la, eis que o juiz de primeiro grau não é o único destinatário das provas. As provas que o convenceram podem não convencer o tribunal de segundo grau. Pode também a parte pretender com a nova prova desmentir a verdade fática apresentada pelas provas anteriormente produzidas.

Como o deferimento das provas no saneador não é imediatamente agravável, pode a matéria ser reapreciada pelo tribunal como preliminar da apelação (art. 963, parágrafo único do projeto). Há preclusão para o juiz de primeiro grau, não para o juízo da apelação.

Cada uma das partes pode desistir das provas que requereu, embora já deferidas, assim como pode o juiz dispensar a produção de provas que determinou de ofício. Parece-me, entretanto, que há um caso em que essa liberdade deve sofrer limitações. Refiro-me à prova pericial, requerida por uma das partes ou determinada de ofício pelo juiz. Se a parte que não requereu a produção da prova formulou quesitos ou se o perito iniciou o trabalho pericial (art. 431-A atual e 458 do projeto), o que normalmente ocorre depois de arbitrados e depositados os seus honorários, já não pode mais a parte, que requereu a perícia, ou o juiz que a determinou de ofício, dispensá-la. A perícia deferida criou para a parte que não a requereu expectativa de desenvolvimento do processo que pode tê-la influenciado a requerer ou a deixar de requerer outras provas, a praticar ou a deixar de praticar outros atos, frustrando a previsibilidade de que deve revestir-se a marcha do procedimento.

\subsection{A preclusão das decisões de mérito proferidas no saneador}

O nosso sistema processual não tem admitido, exceto em certos procedimentos especiais, como o da ação de prestação de contas (arts. 535 a

\footnotetext{
${ }^{9}$ No mesmo sentido, ROCHA, Raquel Heck Mariano da, ob. cit., p.145.
} 
539 do projeto), a fragmentação do julgamento do mérito da causa em decisões sucessivas, porque as regras do procedimento das ações de conhecimento determinam a instrução simultânea de todas as questões de fato e de direito, ainda que algumas constituam pressupostos do acolhimento de outras. O projeto ora examinado acena com a possibilidade do que se tem denominado de sentença parcial, quando, no art. 118, inciso $\mathrm{V}$, confere ao juiz o poder de "alterar a ordem de produção dos meios de prova, adequando-os às necessidades do conflito, de modo a conferir maior efetividade à tutela do bem jurídico". Também prevê o projeto a prolação de decisões interlocutórias de mérito, recorríveis por agravo de instrumento (art. 969, inciso II). Ficará, portanto, o juiz autorizado a instruir separadamente a questão prejudicial, decidindo-a através de decisão interlocutória, e prosseguindo com os demais atos instrutórios para preparar o julgamento final do pedido.

Também no saneador pode o juiz considerar-se apto a resolver determinadas questões de direito material, nos casos de tutela de urgência ou da evidência, sem encerrar o processo ou a sua fase cognitiva. A tutela de urgência poderá ser sempre revogada ou modificada pelo próprio juiz, independentemente da alteração das circunstâncias fático-jurídicas que a determinaram (art. 283 do projeto), "exceto quando um ou mais pedidos cumulados ou parcela deles mostrar-se incontroverso, caso em que a solução será definitiva". Não me parece conveniente esta última ressalva, pois sempre a tutela de urgência terá resultado de cognição sumária, mantendo a sua instrumentalidade, ainda que antecipatória, em relação ao pedido principal, o que, a meu ver, deve impedir a sua sobrevivência em caso de improcedência do pedido principal ou de extinção do processo sem resolução do mérito (art. 284, inciso III). Essa, aliás é a solução do código italiano (art. 186-bis, n.3) (MANDRIOLI, 2011, p.112 e ss). Também a tutela da evidência, apesar de não prevista expressamente no projeto a sua revogabilidade, parece-me inerente à cognição não exaustiva de que resulta tal provimento, salvo na decisão de pedido incontroverso (art. 278, II), que a meu ver merece a mesma crítica feita a hipótese análoga de tutela de urgência.

Já eventual julgamento antecipado de parte do mérito no saneador, salvo se impugnado por agravo de instrumento (art. 271, parágrafo único, e art. 969, inciso II), que deverá te resultado de cognição exaustiva, não poderá ser reapreciada pelo juiz de primeiro grau até a sentença final pela preclusão pro iudicato, aderindo à coisa julgada ou ao seu efeito preclusivo que decorrerão da sentença final de mérito. 


\section{CONCLUSÃO}

A reflexão aqui empreendida não exaure o tema. Muitas questões aqui mencionadas mereceriam ser aprofundadas. Outras, não referidas, têm chamado a atenção da doutrina, especialmente no debate em torno da ampliação do espaço de autonomia das partes no processo de inspiração predominantemente publicista, como tem sido o nosso: a possibilidade de transação, que afaste a preclusão, a renunciabilidade da preclusão, o respeito às preclusões na modificação do procedimento ou da competência, a prorrogação de prazos peremptórios já esgotados, os limites da preclusão do saneador nas instâcias recursais.

Se, do ponto de vista dogmático, o projeto não se afasta substancialmente das diretrizes consolidadas na doutrina e na jurisprudência brasileiras dominantes, em dois aspectos me parece que haverá uma perda qualitativa que poderá ser prejudicial à eficiência do sistema processual: de um lado, a forma exclusivamente escrita do despacho saneador, com todos os desacertos que daí decorrerão na cooperação necessária entre as partes e o juiz quanto aos rumos que o processo deverá seguir na fase subsequente; de outro lado, a recorribilidade do despacho saneador apenas quanto a algumas das questões nele apreciadas (tutelas de urgência e da evidência, decisões de mérito, rejeição de alegação de convenção de arbitragem, decisão sobre gratuidade de justiça, etc., segundo o art. 969) e não quanto a outras (rejeição da carência da ação, fixação dos pontos controvertidos, admissão ou inadmissão de provas, acolhimento ou rejeição da argüição de incompetência), o que poderá provocar a continuidade do processo eivado de nulidade, cuja decretação posterior acarretará a inutilização de todos os atos praticados ou de muitos deles. Ademais, a concorrência no mesmo saneador de partes agraváveis e de outras não agraváveis certamente provocará um reexame fragmentado do tribunal sobre essa importante decisão, que poderá ter reflexos negativos na ordenação da futura marcha do processo.

Espero que estes comentários possam de algum modo contribuir para o debate e, se possível, a compreensão e o aperfeiçoamento do projeto.

\section{REFERÊNCIAS}

BANACLOCHE PALAO, Julio, Las otras finalidades de la audiencia previa al juicio. In BANACLOCHE PALAO, Julio et al. EI tratamiento de las cuestiones procesales y la audiencia previa al juicio en la Ley de Enjuiciamiento Civil. 2. ed. Navarra: Civitas Thomson Reuters, 2009. 
BAPTISTA, José João. Processo civil I - Parte Geral e Processo Declarativo. 8.ed. Coimbra: Coimbra Editora. 2006.

BARBOSA MOREIRA, José Carlos. Saneamento do processo e audiência preliminar. In: Temas de Direito Processual. Quarta Série. São Paulo: Saraiva, 1989.

BÜLOW, Oskar Von. La teoria de las excepciones procesales y los presupuestos procesales. Buenos Aires: EJEA. 1964.

BUZAID, Alfredo. Do despacho saneador. In: Estudos de Direito. São Paulo: Saraiva. 1972.

BUZAID, Alfredo. Exposição de Motivos do Anteprojeto de Código de Processo Civil (1964). In: Código de Processo Civil. São Paulo: Editora Saraiva. 1967.

CAMPOS, Francisco. Exposição de Motivos do Ministro da Justiça. In:

Código de Processo Civil. São Paulo: Editora Saraiva, 1967.

CAPPELLETTI, Mauro. Procédure Orale et Procédure Écrite. Milano: Giuffrè, 1971.

CARNELUTTI, Francesco. Sistema de derecho procesal civil, volume III. Buenos Aires: UTEHA Argentina, 1944.

CHIOVEnDA, Giuseppe, Instituições de Direito Processual Civil, vol. III. São Paulo: 2C" edição, Saraiva. 1965, p.156

CHIOVENDA, Giuseppe, Cosa giudicata e preclusione. In: Saggi di diritto processuale civile (1894-1937), vol. III. Milano: Giuffrè. 1993.

DE SANTIS, Francesco. Riforme processuali e "disponibilità" del regime preclusivo. In: Rivista trimestrale di diritto e procedura civile, ano LVIII. Milano: Giuffrè, 2004.

DINAMARCO, Cândido Rangel. A reforma do Código de Processo Civil. São Paulo: Editora Malheiros. 1995.

. A reforma da reforma. 6.ed. São Paulo: Editora Malheiros, 2003.

GRECO, Leonardo. Instituições de Processo Civil. 3.ed. Rio de Janeiro: Forense, 2011. 
MANDRIOLI, Crisanto. Diritto processuale civile. Torino: G. Giappichelli. 2011. v.II.

MARINONI, Luiz Guilherme; MITIDIERO, Daniel. O projeto do CPC:crítica e propostas. São Paulo: Editora Revista dos Tribunais, 2010.

MESQUITA, José Ignacio Botelho de et al. Questões de ordem pública: revisíveis ad infinitum? In: ASSIS, Araken de et al. Direito Civil e Processo:Estudos em homenagem ao Professor Arruda Alvim. São Paulo: Editora Revista dos Tribunais, 2007.

MURRAY, Peter L.; STÜRNER, Rolf. German Civil Justice. Durham: Carolina Academic Press, 2004.

OLIVEIRA, Carlos Alberto Alvaro. Do formalismo no processo civil: proposta de um formalismo valorativo. 3. ed. São Paulo: Saraiva, 2009.

REIS, José Alberto dos. Código de Processo Civil anotado. 3. ed. Coimbra: Coimbra Editora, 1981. v.3.

SICA, Heitor Vitor Mendonça. Preclusão processual civil. São Paulo: Editora Atlas, 2006.

TARUFFO, Michele. Una alternativa a las alternativas: modelos de resolución de conflitos. In: Páginas sobre justicia civil. Madrid: ed. Marcial Pons, 2009.

THEODORO JÚNIOR, Humberto. A preclusão no processo civil. In: Revista Jurídica n.273, julho de 2000. São Paulo: Notadez Informação. VARANO, Vincenzo. Organizzazione e garanzie della giustizia civile nell'Inghilterra moderna. Milano: Giuffrè, 1973.

Recebido em: 2012-05-28 Aprovado para publicação em: 2012-07-02

Como citar: GRECO, Leonardo. Aspectos da decisão saneadora sob a perspectiva do Novo Código de Processo Civil. Scientia Iuris, Londrina, v.16, n.1, p.83-112, jul.2012. DOI: 10.5433/2178-8189.2012v16n1p83. 